\title{
The relation between external governance environment and over-investment: Evidence from industry regulation
}

\author{
Kejing Chen, Yanxi Li, Kung'unde Goodluck Marco and Yiyu Wang*
}

Dalian University of Technology, Dalian, China

\section{H R O N I C L E \\ A B S T R A C T}

\section{Article history:}

Received May 4, 2014

Accepted 24 September 2014

Available online

September 292014

External Institutional Environment

Industry Regulation

Over-investment

Distribution Characteristics

\begin{abstract}
Based on the Law and Finance theory, and the regulatory capture theory, external governance environment and industrial regulations can exert a certain influence on corporate overinvestment. On the basis of qualitative analysis of the relationship between external governance environment and corporate over-investment under different industrial regulation conditions, this paper, using data of non-financial companies listed in Shanghai and Shenzhen Stock Exchanges in the period 2001-2010, describes the regional distribution characteristics of over-investment of Chinese listed companies, and establishes an OLS regression model of the relationship between external governance environment and over-investment. The study respectively groups data from regulated and non-regulated industries as a sample and empirically tests the OLS regression model. Results show that: from the perspective of economic geography, there exists a local spatial cluster phenomenon in the distribution of over-investment of listed companies in regulated industries, while non-regulated industries conform to no regularity. In regulated industries, external governance environment factors (level of government intervention, rule of law and financial development) may exert a significant negative influence on the degree of over-investment of listed companies, but on non-regulated industries, their effect is reversed. Also, government intervention, legal enforcement and financial development are positively correlated to over-investment. Further research indicates that, compared with government intervention and financial development, legal enforcement influences over-investment the most.
\end{abstract}

\section{Introduction}

The market mechanism is not perfect. In some economic fields, mainly fields in which exist natural monopoly, economic externalities and the production of public goods, malfunction may occur. Therefore, the government needs to regulate many industries in the economic fields, which are related to peoples' livelihoods. In China, regulated industries mainly refer to industries that involve national security, natural monopoly, provide important public goods and services along with mainstay industries and high-tech industries. Due to the existence of government regulations, regulated and non-regulated industries show great differences in the investment decision-making. And the manifestation and economic consequences of this difference have drawn a great attention of

*Corresponding author.

E-mail addresses: mrliyx@dlut.edu.cn (Y.Wang) 
academics and practitioners. Studies show that enterprises in regulated industries have a tendency of over-investing so as to realize more absolute profits (A-J effect) (Averch \& Johnson, 1962; Takayama, 1969). Many literatures study over-investment behavior from the information asymmetry theory, agency theory, free cash flow theory, risk preference theory and overconfidence theory, and have so far achieved fruitful results. La Porta et al. (1998, 1999, 2003) find in their study that external governance environment has an important impact on enterprise's business decisions, and this has provided a new perspective for follow-up studies. Perotti and Thadden (2006), Djankov et al. (2007) and Bergman and Nicolaievsky (2007) confirm that the external governance environment such as legal system, religion, and social culture also have an important influence on enterprise's business decisions. The external governance environment with Chinese characteristics paves way for good corporate finance practices, a phenomenon, which is rooted in corporate investment behavior and differs considerably from Western countries. The corporate investment behavior, which is rooted in this particular phenomenon is also different from western countries. In China, the problem of enterprises' investment hunger is not caused irrationally, but rather a kind of rational choice to adapt to the external governance environment (Williamson, 2000). Therefore, it is of important theoretical and practical significance to study the effects of different external governance environment on enterprise over-investment and then apply the transnational comparative framework proposed by La Porta et al. (1998) to compare China's regional differences. Given this, we build the over-investment econometric model and draw over-investment regional distribution characteristic pattern of China's listed companies. We also examine the influence of external governance environment on overinvestment behavior of regulated and non-regulated industries, and analyze what causes the difference in the influence.

\section{Review of the relevant studies and research hypotheses}

\subsection{Review of relevant studies}

Broadly speaking, North (1990), the Nobel laureate in economics, argues that external governance environment is a set of tools, including; political, social, and legal rules, that are used to establish the foundation for production, exchange, and distribution, which constitutes the incentive mechanism of the human political or economic transactions trading behavior. In a narrow sense, Chinese scholars Xia and Fang (2005) suggest that external governance environment should at least include property rights protection, governance, rule of law, market competition, credit system, contract culture, etc. Studies have shown that enterprises from countries in economic transition face greater external uncertainties. They must be quick to react to the information about institutional changes and timely adjust production and management decisions. Since La Porta et al. (2003) established the law and finance theory, a number of scholars have conducted various research works on firm value (Black, 2001), capital structure (Pagano \& Volpin, 2005), earnings management (Chaney et al., 2011; Lang et al., 2006) and other issues from the external governance environment perspective. Their findings indicate that enterprises' micro-level operating decisions are largely influenced by the external governance environment.

In recent years, scholars have gradually carried out research works related to corporate investment behavior from the external governance environment perspective. Levine and Zervos (1998) finds that the level of financial development has a significant impact on corporate investment behavior, while Simon et al. (2002) finds that the level of property rights protection and the willingness to invest are directly related. In addition, Bai et al. (2006) points out that there will be inefficient over-investment in state-owned listed companies in order to provide more jobs, and pay more taxes. Other scholars study the corporate over-investment using China's special external governance environment. For instance, Yang and Hu (2007) studies the relationship between institutional environment and overinvestment of the free cash flows from the aspects of government intervention and financial development, respectively. The study finds that local government control and government intervention will increase over-investment of free cash flow, while financial development will reduce 
the over-investment of free cash flow. Industry regulations originate from market failures. Though we recognize that market failure is a necessary but not sufficient condition for implementing government regulations, but government control is still the dominant choice to govern market failures. Industry regulations are part and parcel of the development process from a planned economy to a market economy in China. On the one hand, since regulated industries have the characteristics of economies of scale, industry regulations can effectively prevent efficiency losses caused by excessive competition. On the other hand, since regulated industries have relatively large sunk costs, industry regulation can effectively prevent productivity decline caused by excessive competition. China's regulated industries are related to peoples' livelihood with a strong administrative features. Strong barriers to entry, low transaction costs and price monopoly are the advantages that make it easy for regulated industries to obtain excess economic profit. However, from efficiency point of view, regulated industries are less efficient compared to non-regulated industries.

After reviewing the literature above, to our knowledge, we can find several shortcomings in the existing literature, namely: First, the existing literature is limited to some of the external governance environment factors, thus not fully reflecting the influence of the external governance environmental factors on corporate over-investment behavior. Second, existing studies have not revealed the mechanism of action of industrial regulations over the relationship between external governance environment and over-investment. And, third, though a number of scholars have conducted detailed studies on enterprise over-investment problem, none of them studies regional distribution characteristics of over-investment of Chinese listed companies. This paper intends: to apply the law and finance theory to analyze the influencing mechanism of external governance environment on corporate over-investment; to employ regulatory capture theory to explore the role of industry regulation in the impact of external governance environment on corporate over-investment; and, to reveal industry regulation's mechanism of action towards the relationship between the external governance environment and over-investment. We hope to uncover the investment black-box of regulated industries.

\section{2 research hypothesis}

This paper combines data availability and scientific rationality of proxy variable selection, and considers external governance environment to be mainly composed by government intervention, the level of rule of law and the level of financial development. Considering that the aspects of the three main external governance environment factors are more fundamental and exogenous as compared to ownership system, system of board of directors, information disclosure system, independent auditing system, etc., thus, these factors will affect contracts signing, the cost of completed transactions as well as the efficiency of corporate governance. Figure 1 shows the transmission mechanism of the influence of external governance environment on corporate over-investment behavior. As a response to the external governance environment, the internal mechanism of corporate governance originated within the factors of external corporate governance environment and plays an important regulatory role in making corporate management decisions. In short, external governance environment significantly impacts internal mechanism of corporate governance, thereby affecting investment, financing, and other business decisions, which ultimately affects enterprise's over-investment behavior.

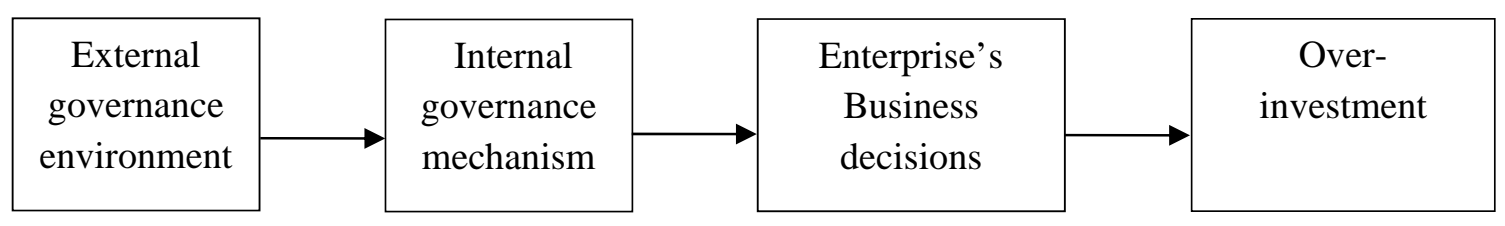

Fig. 1. Transmission Mechanism of the influence of External Governance Environment on 
The role played by the government in a market economy has a crucial impact on the country's economic development. Shleifer and Vishny (2002) indicates that, in the economy the government plays three roles, namely, "watchman", "helping hand", and, "grabbing hand". In the economic transition period, the government of China has an important influence on resources allocation, thus impacting investment behaviors of listed companies through policies, administrative directives, etc. On the one hand, regulated industries are related to lifelines of the national economy. Regulated industries and the government are closely associated politically, and there is tacit alliance between the two. In order to maintain price control, administrative license, excess profits, and other special interests, regulated industries must help in the promotion of government officials, and in achieving social goals (Shleifer \& Vishny, 1994), namely, boosting local GDP growth and promoting employment through increased investment hence inducing irrational excessive investment. According to the regulatory capture theory, over-investment behavior is an effective "rent-seeking investment", and regulators would normally be "captured". On the other hand, due to the heterogeneity of the industry, regulated industries are more likely to be national policy beneficiaries. The 4 (four) trillion RMB investment plan implemented in 2008 largely benefits oil, coal, steel, transportation and other regulated industries, and such massive capital inflows encourage regulated industries to invest more. As there is a huge availability of funds, companies can still obtain state subsidies even when investment projects fail. Thus, this makes the regulated industries prone to over-investment behavior when subjected to government intervention. Non-regulated industries can generally be considered as fully competitive industries. Since the main objective of investment decisions is profit maximization, then investment policies of non-regulated industries are less affected by government intervention (Roques \& Savva, 2009), as over-investment decisions that are damaging to profit maximization would not be an option even with government intervention. Based on the analysis above, we propose the following hypotheses:

$\mathrm{H}_{1 \mathrm{a}}$ : In regulated industries, government intervention and over-investment in listed companies are positively correlated.

$\mathrm{H}_{1 \mathrm{~b}}$ : In non-regulated industries, government intervention and over-investment in listed companies are negatively correlated.

Law and Finance is an extension of Law and Economics that sprung up in the 1970s. The law and finance theory pioneered by La Porta et al. (1998) analyzes the relationship between law and financial development at the national level. The results show that legal protection for investors can promote development of financial markets and intermediaries, thereby promoting business investment and economic growth. A study by Cambini and Rondi (2010) on the European energy industry shows that legal system has an important impact on investment decisions of regulated industries. Enterprise managers are inclined to have "managerial imperialism" to pursue large investment, and they may pursue self-interests due to the availability of resources at their disposal. According to the regulatory capture theory, the regional control rights spillover phenomenon is more extensive in regions with relatively low levels of the rule of law, thus, regulators and business managers can easily conspire to sign implicit contracts for personal gain. Due to the protection of implicit contracts, managers in regulated industries barely pay the corresponding price for their actions even when the investment decisions lead to failures. Consequently, the tendency of "empire building" by managers in regulated industries is more rampant. Therefore, in regions with relatively low levels of the rule of law, the over-investment behavior is more likely to be seen in regulated industries. Simon et al. (2002) further their research on the subject by investigating enterprise data of five countries from East Europe and the former Soviet Union (Russia, Poland, Romania, Slovakia and Ukraine). They examined the relationship between property right and entrepreneur investment. The results show that property rights protection and the corporate's willingness to invest are positively correlated. Since these countries have imperfect legal systems and less efficient law enforcement, property rights of nonregulated industries are often threatened and destroyed by underworlds or other underground organizations without the government as a "protective umbrella". In order to obtain effective property 
rights protection, companies must incur additional costs. Therefore, in regions with relatively low level of the rule of law, enterprises in non-regulated industries are rarely willing to increase investment, hence less to no chance of the existence of over-investment. Based on the above analysis, we propose the following hypotheses:

$\mathrm{H}_{2 \mathrm{a}}$ : In regulated industries; level of the rule of law and over-investment in listed companies are negatively correlated.

$\mathrm{H}_{2 \mathrm{~b}}$ : In non-regulated industries; level of the rule of law and over-investment in listed companies are positively correlated.

A country's financial development has a significant impact on the investment decisions of enterprises. A study García-Herrero et al. (2006) argues that progress in the financial sector can promote market reforms in state-owned banks, thus making them more for economic purposes rather than political when allocating loans (especially, long-term loans) to regulated industries. This will restrict sources of investment funds in regulated industries, consequently constraining overinvestment. In addition to above, Fang (2006) finds that the more developed financial markets are, the higher capital allocation efficiency is, and, the more developed financial markets are, the higher independence of banks is. Under the circumstances, bank's credit decisions are more based on economic principles rather than government interventions. This gives non-regulated industries an opportunity to obtain funds necessary for investment, thus making it easy to formulate extensive investment patterns with high investment and low efficiency. Based on the above analysis, we propose the following hypotheses:

$\mathrm{H}_{3 \mathrm{a}}$ : In regulated industries; level of financial development and over-investment in listed companies are negatively correlated.

$\mathrm{H}_{3 \mathrm{~b}}$ : In non-regulated industries; level of financial development and over-investment in listed companies are positively correlated.

\section{Research design}

\subsection{Sample selection and Data sources}

We select data from the annual report of A-share listed companies from 2001 to 2010 as the sample data and use the following three ways to remove noise: (1) excluding listed companies under special treatment (ST) or particular transfer (PT) during 2001-2010; (2) excluding listed financial companies; And, (3) excluding listed companies with incomplete data. After the exclusion, we obtain a total of 8016 observations. Financial data of the listed companies are all from RESSET financial research databases and CCER China's economic and financial databases. External governance environment data are from "NERI INDEX of Marketization of China's Provinces - 2009 Report" (Hereinafter referred to as the "REPORT") compiled by Fan et al. (2010). The REPORT is a relatively authoritative report on the external governance environment in China as it evaluates the process of marketization of various regions in the country from five aspects, namely: "the relationship between government and market", "the development of a non-state-owned economy", "the development of goods market", "the development of factor market", and, "the development of market intermediary organizations and the legal environment”.

\subsection{Model and Variables}

This paper mainly studies over-investment of listed companies, which is specifically defined here as investments that allocate enterprise's resources in projects with negative NPV (Jensen, 1986). At present, main models that measure over-investment include; investment-cash flow sensitivity model of FHP (Fazzari et al., 1988), the Vogt's (1994) cash flow/investment opportunities cross-term discriminant model, and the residual measurement model proposed by Richardson (2006). Based on 
the free cash flow theory, Richardson constructs a model to reasonably estimate the enterprise's normal level of investment. He divides enterprises' new investment into expected investment spending and unexpected investment spending determined by factors such as; growth, capital structure, cash flow, profitability, size, etc. Through this model, a modest investment level can be reasonably calculated. When the level of real investment is greater than the value predicted by the model, then there exists over-investment, and the difference between the two values is the degree of over-investment. The Richardson's model is favored by many scholars (Biddle et al., 2009; D’Mello \& Miranda, 2010; Ahmed \& Duellman, 2011) for its rational design and easy execution. This study builds its model (1) for measuring over-investment based on Richardson's model. The model is as follows below:

$$
I N V_{t}=\alpha_{0}+\alpha_{1} \text { Gro }_{t-1}+\alpha_{2} \operatorname{LeV}_{t-1}+\alpha_{3} C f o_{t-1}+\alpha_{4} \text { Roa }_{t-1}+\alpha_{5} \operatorname{Siz}_{t-1}+\alpha_{6} I N V_{t-1}+\alpha_{7} \text { Age }_{t-1}+\alpha_{i} \text { Industry }+\alpha_{j} \text { Year }+\varepsilon
$$

where: $\alpha_{0}$ is a constant; $\alpha_{1} \sim \alpha_{7}$ are coefficients of each variable; $\alpha_{i}$ is the regression coefficient of the industry dummy variables, $\mathrm{i}=8,9,10 \ldots 18 ; \alpha_{j}$ is the coefficient of the year dummies, $\mathrm{j}=19,20,21 \ldots$ 23 ; $t$ is the year of the sample, $\mathrm{t}=2001,2002,2003 \ldots 2010 ; \varepsilon$ is the residual term -- when $\varepsilon$ is greater than 0 , it is the degree of over-investment, while it is the degree of under-investment when it is less than 0 . Variables in the model (1) are defined in Table 1 below:

\section{Table 1}

Variables setting and calculation in the Model (1)

\begin{tabular}{|c|c|c|c|}
\hline Variable & Variable Name & Variable & Variable Calculation \\
\hline $\begin{array}{l}\text { Dependent } \\
\text { variable }\end{array}$ & new capital investment & $I N V_{t}$ & $\begin{array}{l}\text { (an increase in fixed assets, construction in progress, and long-term } \\
\text { investments in the yeart/ total assets at the beginning of year } r_{t} \text { ) }\end{array}$ \\
\hline \multirow{7}{*}{$\begin{array}{l}\text { Explanatory } \\
\text { variables }\end{array}$} & enterprise growth ability & $\mathrm{GrO}_{t-1}$ & revenue growth rate of year $_{t-1}$ \\
\hline & asset-liability ratio & $L e v_{t-1}$ & (total liabilities / total assets), at the end of year ${ }_{t-1}$ \\
\hline & cash flow from operations & $C f o_{t-1}$ & (net operating cash flow/ total assets), at the end of year $\mathrm{t}_{\mathrm{t}-1}$ \\
\hline & profitability & $\operatorname{Roa}_{t-1}$ & the ROA of year $\mathrm{t}_{-1}$ \\
\hline & enterprise scale & $\operatorname{Siz}_{t-1}$ & natural logarithm of total assets at the end of year $\mathrm{r}_{\mathrm{t}-1}$ \\
\hline & $\begin{array}{l}\text { additional capital investment to prior } \\
\text { investment }\end{array}$ & $I N V_{t-1}$ & $\begin{array}{l}\text { (an increase in fixed assets, construction in progress and long-term } \\
\text { investments in the year } \mathrm{r}_{\mathrm{t}-1} / \text { total assets at the beginning of year } \mathrm{r}_{\mathrm{t}-1} \text { ) }\end{array}$ \\
\hline & listed age & Age $_{t-1}$ & the number of years a company has been listed. \\
\hline \multirow{2}{*}{$\begin{array}{l}\text { Control } \\
\text { variables }\end{array}$} & industry dummy variable & Industry & 11 industry dummies are set to control the influence of industry difference \\
\hline & year dummy variable & Year & 5 year dummies are set to control the effect of macro-economy in the year. \\
\hline
\end{tabular}

After measuring model (1), we can get the degree of enterprise's over-investment. To reveal the influence of industry regulations on the relationship between the external governance environment and corporate investment, the paper builds model (2). Considering the principle factors affecting over-investment are agency costs and cash flow from financing, we refer studies Ahmed and Duellman (2011) and Singh and Davidson III(2003) and control major shareholders fund occupancy, agency costs, and cash flow from financing activities, and other factors which affect over-investment. To control the influence of macroeconomic situation in different years on enterprise investment decisions, we add the year dummy variable. In summary, model (2) is built as follows:

Over_INV ${ }_{t}=\beta_{0}+\beta_{1}$ Gov $_{t}+\beta_{2}$ Law $_{t}+\beta_{3}$ Fin $_{t}+\beta_{4}$ Orecta $_{t}+\beta_{5}$ Agency $_{t}+\beta_{6}$ Issue $_{t}+\beta_{j}$ Year $+\eta$

where: $\beta_{0}$ is a constant; $\beta_{1} \sim \beta_{6}$ are coefficients of each variable; $\beta_{j}$ is the annual regression coefficient of year dummies; $\mathrm{j}=7,8,9 \ldots 11$; $t$ is the year of the sample, $\mathrm{t}=2001,2002,2003 \ldots$ 2010; and, $\eta$ is the residual term.

Variables in the model (2) are defined in Table 2 below: 
Table 2

Variables setting and calculation in Model (2)

\begin{tabular}{|c|c|c|c|}
\hline Variable type & Variable name & Variable & Variable calculation \\
\hline $\begin{array}{l}\text { Dependent } \\
\text { variable }\end{array}$ & Over-investment & Over_INV & $\begin{array}{l}\text { the degree of over-investment of year } \text {, i.e., the positive residual value in } \\
\text { regression of the Richardson's model }{ }^{[44]}\end{array}$ \\
\hline \multirow{3}{*}{$\begin{array}{l}\text { Explanatory } \\
\text { variables }\end{array}$} & $\begin{array}{l}\text { Government intervention } \\
\text { index }\end{array}$ & Gov $_{t}$ & $\begin{array}{l}\text { "reducing government intervention to enterprises" index of } \text { year }_{t} \text { (from the } \\
\text { REPORT). }\end{array}$ \\
\hline & The rule of law index & $L^{2} w_{t}$ & financial Industry Marketization index of year $\mathrm{f}_{\mathrm{t}}$ (from the REPORT). \\
\hline & $\begin{array}{l}\text { Financial development } \\
\text { index }\end{array}$ & Fin $_{t}$ & $\begin{array}{l}\text { "reducing government intervention to enterprises" index of } \text { year }_{t} \text { (from the } \\
\text { REPORT). }\end{array}$ \\
\hline \multirow{4}{*}{ Control variables } & $\begin{array}{l}\text { Major shareholders fund } \\
\text { occupancy }\end{array}$ & Orecta $_{t}$ & (other receivables/ total assets), at the end of year ${ }_{t}$ \\
\hline & Agency cost & Agency $_{t}$ & (administration expenses/ total assets), at the end of year $\mathrm{r}_{\mathrm{t}}$ \\
\hline & Cash flow from financing & Issue $_{t}$ & (cash flow from financing/ total assets), at the end of year $r_{t}$ \\
\hline & Year dummies & Year & 5 year dummies are set to control the effect of macro-economy in the year. \\
\hline
\end{tabular}

On the choice of regulated industries, there are three main criteria as follows: First, according to the principles of the strategic adjustment of state-owned economy, regulated industries are divided into; mining, petroleum, chemical, plastic, metal, non-metal, electricity, gas and water production and supply industries, as well as, transportation, warehousing, IT, etc., industries. Second, according to the need for government approval on investment projects, regulated industries are defined as; electricity, water, gas, coal, petroleum, iron and steel, nonferrous metals, aerospace, salt mining, tobacco, railways, telecommunications, postal services, finance and other industries. And, third, according to industry barriers to entry level, regulated industries are defined as construction and engineering, energy equipment and services, metals, non-metallic, mining, automotive, financial services, electricity, gas, and water utilities complexes, road and rail transport, media, maritime, aviation and aviation logistics and freight forwarding, diversified telecommunications services, and other industries. After the comparative analysis, we find that the above-mentioned three methods differ primarily in the financial sector. Financial sector invests primarily in stocks, bonds, foreign exchange and other forms of monetary value of financial assets which is different from physical investments by normal enterprises. As the financial value of the investment is very unstable and difficult to reasonably evaluate its level of investment and efficiency, thus this article does not take it into account. Meanwhile, because China is in economic transition, the strategic adjustment of stateowned economy has played a huge ideological guiding role, therefore using the method proposed by Xia and Fang (2005) to define regulated industries has certain rationality.

\section{Empirical results and analysis}

\subsection{Descriptive Statistics}

\subsubsection{Descriptive statistics of variables}

After running regression on the sample of 8016 data based on model (1), we found that 3309 show excessive investment behavior, which makes up a 41.28 percent of total sample, leaving 4707 , a $59.72 \%$ of total sample which shows under-investment behavior. Table 3 shows characteristics of the variables' descriptive statistics for the model (2), in which: from the government intervention index, the rule of law index, and financial development index; it can be seen that there exists a huge difference in external governance environment among various areas in China, e.g., government intervention index, whereby, the highest is 12.670 while the lowest is only -2.170 . This is mainly because China is a large country with diversified economic geography and culture, which includes, differences in the path of regional economic development, the impact of unbalanced regional development strategies led by the central government, as well as the distortions caused by the government's actions at all levels under the current decentralized system. These, together, have largely contributed to the regional imbalances of external governance environment in the country. 
Table 3

Descriptive Statistics of Variables in Model (2)

\begin{tabular}{|c|c|c|c|c|c|c|}
\hline Variable & Size & Mean & Median & Min & Maximum & Standard deviation \\
\hline Over_INV & 3309 & 0.130 & 0.082 & 0.000 & 1.110 & 0.164 \\
\hline Gov & 3309 & 7.084 & 7.050 & -2.170 & 12.670 & 3.490 \\
\hline Law & 3309 & 5.696 & 5.640 & -0.400 & 10.900 & 2.748 \\
\hline Fin & 3309 & 8.351 & 8.490 & 0.840 & 12.01 & 2.115 \\
\hline Orecta & 3309 & 0.028 & 0.014 & 0.001 & 0.547 & 0.041 \\
\hline Agency & 3309 & 0.042 & 0.035 & -0.006 & 0.273 & 0.030 \\
\hline Issue & 3309 & 0.042 & 0.027 & -0.581 & 0.617 & 0.104 \\
\hline
\end{tabular}

Note: The minimum value of overinvestment is 0.00007 .

\subsubsection{Regional Distribution of Over-investment in Chinese listed companies}

To intuitively report the regional distribution of over-investment in listed companies in China, this paper divides the ten years' average over-investment level of listed companies from the country's 31 provinces, autonomous regions and municipalities (excluding; Taiwan, Hong Kong and Macao S.A.R.) into three groups from low to high, where, 10 provinces with the lowest over-investment level are in group 1, 10 provinces with the highest over-investment level are in group 3, and, the remaining 11 provinces are in group 2. Table 4 displays the regional distribution of over-investment under both groups, regulated and non-regulated industries. On the one hand, the top half shows the regional distribution of over-investment under regulated industries. From the perspective of economic geography, the distribution of over-investing companies under regulated industry show significant local spatial clusters. Specifically, the lowest level of over-investing enterprises group is mainly found in the eastern region of the country, while the highest degree of over-investing enterprise group is in the western region, with the remaining extent of over-investing enterprises group centered in the central region. On the other hand, the bottom half shows the regional distribution of over-investment under non-regulated industries, and overall its extent is significantly smaller than regulated industry. The lowest level of over-investment enterprise group is mainly found in the central and western regions, while distribution of the remaining two groups follow no specific pattern.

Because of the differences in economic geography and culture among various regions in China, as well as the path of economic development and non-balanced regional development strategies led by the central government, the external governance environment of various regions also show a clear imbalance. Eastern region's external governance environment in the eastern region tops other regions' followed by the central region, and the western region has the worst external governance environment. Combining the features of regional distribution of over-investment in the country, we find an interesting phenomenon: under the regulated industries, the external governance environment of the regions with lower degree of over-investment is relatively good, while the external governance environment of the region with higher degree of over-investment is relatively poor. On the other hand, under non-regulated industry, the external governance environment of the regions with lower degree of over-investment is relatively poor. So, is this phenomenon typical? This will be verified through regression analysis in the empirical analysis section.

It is worth noting that, the investment behavior of a listed company is strongly associated with the external governance environment of the region the investment takes place. But, in this paper, the regional distribution of over-investment is based on where the listed company is registered rather than where the investment takes place. We feel is imperative to mention that, as: on one hand, it is difficult to obtain investment information from the regions of investment since financial data of the listed companies do not disclose specific details of investment projects, hence it is difficult to study the impact of external governance environment on over-investment in these investment regions. On the other hand, China's company law and company registration regulations require companies to engage in business at their registered residential address. According to the principles of territorial management, investment, financing and other business activities will be directly subjected to supervision by the local industry and commerce departments, as well as taxation, auditing and other 
departments at the area of registration. This also shows that local area's external governance environment can influence enterprise's over-investment behavior. Thus, from this, the study's choice of area of registration in place of investment location may as well be advantageous.

\section{Table 4}

Regional distribution of over-investment under regulated and non-regulated industries

Group $1 \quad$ Group $2 \quad$ Group 3

\begin{tabular}{|c|c|c|c|}
\hline Regulated Industry & $\begin{array}{l}\text { Beijing, Tianjin, Shandong, Jiangsu, } \\
\text { Shanghai, Zhejiang, Hunan, Yunnan, } \\
\text { Guangxi, Guangdong }\end{array}$ & $\begin{array}{l}\text { Heilongjiang, Inner Mongolian, } \\
\text { Liaoning, Shanxi, Hebei, Henan, Anwei, } \\
\text { Hubei, Chongqing, Jiangxi, Hainan }\end{array}$ & $\begin{array}{l}\text { Jilin, Xinjiang, Gansu, Ningxia, } \\
\text { Shaanxi, Fujian, Guizhou, Sichuan, } \\
\text { Qinghai, Tibet }\end{array}$ \\
\hline Non- & $\begin{array}{l}\text { Heilongjiang, Jilin, Inner Mongolian, } \\
\text { Gansu, Qinghai, Shanxi, Shandong, } \\
\text { Sichuan, Hunan, Jiangxi }\end{array}$ & $\begin{array}{l}\text { Liaoning, Hebei, Henan, } \\
\text { Chongqing, Shaanxi, } \\
\text { Guangdong, Yunnan, Xinjiang, Hainan }\end{array}$ & $\begin{array}{l}\text { Beijing, Tianjin, Jiangsu, } \\
\text { Shanghai, Zhejiang, Anhui, Hubei, } \\
\text { Guizhou, Tibet, Ningxia }\end{array}$ \\
\hline
\end{tabular}

\subsection{Comparative Analysis between the Groups}

To analyze over-investment differences between regulated and non-regulated industries, we use the Independent samples t-Test. Table 5 shows comparative analysis results between the regulated and non-regulated industries. From Table 5, we can see that the degree of over-investment in the regulated industries group is significantly higher than in the non-regulated industries group. Specifically, the average of over-investment in the regulated industries group is 0.150 , while in the non-regulated industries group is 0.114 , and the mean difference between the two groups is significant at 0.01 level. This conclusion also confirms that the A-J Effect, proposed by Averch et al. and Takayama et al. is an objective reality in China's capital market, that is, regulated industries are more driven to over-investment than non-regulated industries.

Table 5

Independent Samples Test

\begin{tabular}{llll}
\hline & $\begin{array}{l}\text { Regulated industry } \\
\text { Average }\end{array}$ & $\begin{array}{l}\text { Non-regulated industry } \\
\text { Average }\end{array}$ & $\begin{array}{l}\text { Comparison } \\
\text { F-value }\end{array}$ \\
\hline Degree of Over-investment & 0.150 & 0.114 & 42.794 \\
Sample size & 1455 & 1854 & $0.000^{* * *}$ \\
\hline
\end{tabular}

Note: (1) ***, **, * denote significance at; 0.01, 0.05, and 0.10 level, respectively, two-tailed test.

\subsection{Correlation analysis}

We perform the correlation test on the variables in the model (2), and Table 6 shows the results. Among the main concerns, is the possibility that there may exist multicollinearity problem among, "Gov", "Law", and "Fin" as the correlation coefficients between the variables are greater than 0.5. Thus, to avoid this, during regression process, we must separately insert government intervention index, the rule of law index, and financial development index into the model in order to reduce the noise in the findings due to the possible multicollinearity problem. To ensure robustness of the study, we record the variance inflation factor during the regression of model (2). This is detailed below:

Table 6

Correlation Values of Main Variables

\begin{tabular}{|c|c|c|c|c|c|c|c|}
\hline Variable & Over_INV & Gov & Law & Fin & Orecta & Agency & Issue \\
\hline Over_INV & 1.000 & 0.025 & $0.047 * * *$ & 0.027 & $-0.091 * * *$ & $-0.130 * * *$ & $0.185^{* * *}$ \\
\hline Gov & $0.038 * *$ & 1.000 & $0.681 * * *$ & $0.818 * * *$ & $-0.048 * * *$ & 0.004 & $-0.125 * * *$ \\
\hline Law & $0.056 * * *$ & $0.713^{* * *}$ & 1.000 & $0.744^{* * *}$ & $-0.047 * * *$ & $0.066^{* * *}$ & $-0.154 * * *$ \\
\hline Fin & $0.041^{* *}$ & $0.826 * * *$ & $0.762 * * *$ & 1.000 & $-0.061 * * *$ & $0.064 * * *$ & $-0.131 * * *$ \\
\hline Orecta & $-0.160 * * *$ & $-0.075^{* * *}$ & $-0.073 * * *$ & $-0.062 * * *$ & 1.000 & $0.089 * * *$ & $-0.079 * * *$ \\
\hline Agency & $-0.185^{* * *}$ & -0.012 & $0.063^{* * *}$ & $0.050 * * *$ & $0.220 * * *$ & 1.000 & $-0.227 * * *$ \\
\hline Issue & $0.227 * * *$ & $-0.135^{* * *}$ & $-0.153 * * *$ & $-0.140 * * *$ & $-0.072 * * *$ & $-0.246 * * *$ & 1.000 \\
\hline
\end{tabular}

Note: Above the diagonal are the Pearson correlation coefficients, while below are the Spearman correlation coefficients. 


\subsection{Regression analysis}

Table 7 shows results of the regression analysis of model (2). To avoid the multicollinearity problem among the three external governance environment variables, we separately insert one variable at a time into model (2) to run tests. From the impact of government intervention index on corporate overinvestment, the degree of over-investment in regulated industries and government intervention index are negatively correlated at 0.10 significance level $(t=-1.724)$, while the degree of over-investment in non-regulated industries and government intervention index are positively correlated at 0.10 significance level ( $\mathrm{t}=1.647)$, which supports hypotheses H1a and H1b. This conclusion confirms that government intervention in business may have positive as well as negative externalities. Different investment behaviors of enterprises are not only the result of government intervention, but also the enterprises' sub-optimal choices to adapt to the existing external governance environment, the choices which may deviate from the goal of maximizing corporate value. From the effect of the rule of law index on corporate over-investment, the rule of law index is negatively correlated to the degree of over-investment in regulated industries at a 0.05 significance level $(\mathrm{t}=-1.980)$, while the degree of over-investment in non-regulated industries and the rule of law index are positively correlated at a 0.100 significance level $(\mathrm{t}=3.532)$. This also verifies hypotheses $\mathrm{H} 2 \mathrm{a}$ and $\mathrm{H} 2 \mathrm{~b}$. From the influence of financial development index on corporate over-investment, financial development index is negatively correlated to the degree of over-investment in regulated industries at 0.10 significance level $(\mathrm{t}=$ 1.681), while the degree of over-investment in non-regulated industries and financial development index are positively correlated at a 0.100 significance level $(\mathrm{t}=3.057)$, which also proves hypotheses H3a and H3b.

Table 7

Regression Results

\begin{tabular}{|c|c|c|c|c|c|c|}
\hline \multirow[t]{2}{*}{ Variables } & \multicolumn{3}{|c|}{ Regulated industry } & \multicolumn{3}{|c|}{ Non-regulated industry } \\
\hline & Gov & Law & Fin & Gov & Law & Fin \\
\hline Intercept & $\begin{array}{c}0.155^{* * *} \\
(12.576)\end{array}$ & $\begin{array}{c}0.129 * * * \\
(7.510)\end{array}$ & $\begin{array}{c}0.138 * * * \\
(8.540)\end{array}$ & $\begin{array}{c}0.111^{* * *} \\
(8.793)\end{array}$ & $\begin{array}{c}0.094^{* * *} \\
(7.459)\end{array}$ & $\begin{array}{c}0.098^{* * *} \\
(7.590)\end{array}$ \\
\hline Gov & $\begin{array}{l}-0.046^{*} \\
(-1.724)\end{array}$ & & & $\begin{array}{l}0.041^{*} \\
(1.647)\end{array}$ & & \\
\hline Law & & $\begin{array}{c}-0.057 * * \\
(-1.980)\end{array}$ & & & $\begin{array}{c}0.091^{* * *} \\
(3.532)\end{array}$ & \\
\hline Fin & & & $\begin{array}{l}-0.045^{*} \\
(-1.681)\end{array}$ & & & $\begin{array}{c}0.075^{* * *} \\
(3.057)\end{array}$ \\
\hline Orecta & $\begin{array}{l}-0.043^{*} \\
(-1.646)\end{array}$ & $\begin{array}{l}-0.044^{*} \\
(-1.648)\end{array}$ & $\begin{array}{c}-0.042 \\
(-1.586)\end{array}$ & $\begin{array}{c}-0.060 * * \\
(-2.587)\end{array}$ & $\begin{array}{c}-0.060^{* *} \\
(-2.567)\end{array}$ & $\begin{array}{c}-0.058^{* *} \\
(-2.505)\end{array}$ \\
\hline Agency & $\begin{array}{c}-0.109 * * * \\
(-4.194)\end{array}$ & $\begin{array}{c}-0.115^{* * *} \\
(-4.396)\end{array}$ & $\begin{array}{c}-0.112 * * * \\
(-4.292)\end{array}$ & $\begin{array}{c}-0.029 \\
(-1.231)\end{array}$ & $\begin{array}{c}-0.029 \\
(-1.256)\end{array}$ & $\begin{array}{c}-0.029 \\
(-1.243)\end{array}$ \\
\hline Issue & $\begin{array}{c}0.186^{* * *} \\
(7.175)\end{array}$ & $\begin{array}{c}0.191^{* * *} \\
(7.313)\end{array}$ & $\begin{array}{c}0.188^{* * *} \\
(7.229)\end{array}$ & $\begin{array}{c}0.133^{* * *} \\
(5.592)\end{array}$ & $\begin{array}{c}0.139 * * * \\
(5.840)\end{array}$ & $\begin{array}{c}0.136 * * * \\
(5.747)\end{array}$ \\
\hline Year & control & control & control & control & control & control \\
\hline F-Value & $11.509 * * *$ & $11.612^{* * *}$ & $11.452^{* * *}$ & $7.901^{* * *}$ & $8.695^{* * *}$ & $8.442^{* * *}$ \\
\hline Adjusted $\mathrm{R}^{2}$ & 0.307 & 0.308 & 0.306 & 0.230 & 0.241 & 0.237 \\
\hline Sample size & 1455 & 1455 & 1455 & 1854 & 1854 & 1854 \\
\hline
\end{tabular}

Note: The numbers in parentheses are the T value (two-tailed); the variance inflation factor (VIF) of each variable in the regression is much lower than 10, which further indicates that there is no serious multicollinearity in regression equation. Due to limited space, the values are not repeated in the table.

After the comparison, we can see that external governance environment has an inverse effect on overinvestment in both regulated and non-regulated industries. Due to the difference in the industry nature, the effect of external governance environment on corporate over-investment got reversed. Therefore, the basic assumptions of this study are verified. Through comparison we can also see that the rule of law index affects corporate over-investment the most compared to the other two external governance environment variables effect coefficients. For instance, in non-regulated industry, the effect coefficient of the rule of law index is 0.091 which is greater than the effect coefficients of government intervention index and financial development index, which are, 0.041 and 0.075 , respectively. This is also true in regulated industries samples. We can conclude that, of the three 
external governance environment factors, the rule of law index influences corporate over-investment behavior the most. In a market economy, as an important external governance mechanisms, the legal system plays a crucial role and high level of law enforcement can reduce transaction costs in economic activities. The fifth National Congress of the Communist Party of China made the "governing the country according to law and building a socialist country ruled by law" as a major strategic task to be achieved, and China's legal system continues to enhance legal awareness to popular support, as well as improving the rule of law in the country. This change in external governance environment factors has had a major impact on the corporate investment behavior, thus greatly constraining over-investment behavior.

\subsection{Robust Analysis}

\subsubsection{Definition of Over-investment}

Considering Richardson model, there may exist systematic bias as a result of the effect of macroeconomic policies, market conditions, etc., which can cause systematic over-investment problem in listed companies. We divide the residuals of the model (1) regression into three groups sorted according to size, in which the group with the largest residuals is the over-investment sample group.

\subsubsection{Sample Clusters}

While analyzing regional characteristics of over-investment in China, we discovered one problem: there is a large correlation between sample distribution and external governance environment, and, regions with good external governance environment have a relatively large number of listed companies while a number of listed companies in the regions with poor external governance environment is relatively small, and also, there exist some clusters in the sample distribution. The sample size of over-investing enterprises in Shanghai, Guangdong, and Jiangsu is; 514, 339 and 236, respectively, bringing to a total of 1089 , accounting for $32.91 \%$ of the sample, while it is 1 , 9 , and 12 in Ningxia, Qinghai, and Tibet, respectively, for a total of just 22, accounting for only $0.66 \%$ of the total sample. To further investigate whether the sample distribution is related to over-investment, this paper introduces instrumental variables to conduct tests. Main steps are as follows below:

First step, building regression models by setting different governance factors as explanatory variables and then respectively regressing them with each region's sample size $\mathrm{N}$. The specific model is as shown below:

$$
\text { Institution }_{n t}=\rho_{0}+\rho_{1} N_{n t}+\xi
$$

where: from the model (3) above, Institution refers to the government intervention index, the rule of law index, and financial development index; $\rho_{0}$ is constant, $\rho_{1}$ is a variable coefficient; $\mathrm{n}$ stands for regions $(n=1,2,3 \ldots, 31)$; $t$ is the year of the sample $(t=2001,2002 \ldots 2010)$; $\xi$ is the residual.

Second step, seeking instrumental factors by sequentially setting government intervention index, the rule of law index, and the financial development index as the explained variables in model (3) and regress, and extracting regression residuals three times, which are the instrumental variables, namely IVGov, IVLaw, and IVFin. And, the third step, re-testing: this is done by inserting the obtained three instrumental variables in the model (2) as explanatory variables and conduct regression analysis. After examination and analysis, we find that the empirical results don't have substantial changes.

\subsubsection{The external governance environmental data selection}

Since the REPORT for 2010 provides data only for 2003-2007 period, instead of using external governance environment data for 2008-2010, we use the data for 2007, which may impact the 
findings. To eliminate this effect, the article adopts the following four methods to conduct tests: (1) Predicting data of 2008-2010 using the average growth rate of external governance environmental data for 2003-2007; (2) Using linear regression on the external governance environment data of 20032007 to predict the data for 2008-2010 period; (3) Directly using the average of external governance environment data of 2003-2007; and, (4) Only choosing the sample data in 2003-2007. After inspection, we found that the regression results of the four methods are consistent with the previous results above, which further illustrates the robustness of the results of this study.

\section{Conclusion}

We take non-financial corporations listed at Shanghai and Shenzhen in China as our sample, and empirically test the relationship between external governance environment and corporate overinvestment based on the differences between regulated and non-regulated industries. The results reveal that: first, from the perspective of economic geography; the distribution of over-investment in listed companies under the regulated industry shows local spatial clustering phenomenon, while on the other hand non-regulated industry conforms to no regularity. Second, in regulated industries, improvement in the external governance environment can inhibit over-investment behavior, that is, the degree of government intervention, the level of rule of law, and the level of financial development are negatively correlated to over-investment. And, third, further study found that among the factors in external governance environment, the level of rule of law affects over-investment the most.

According to the research findings, we propose the following measures: to begin with, regulators must formulate policies which adapt to local conditions so as to restrict corporate over-investment behavior, and to avoid “one size fits all” regulatory policies, as well as strengthening regional supervision where the over-investment behavior is serious. Second, introduction of the western "costbenefit analysis" to improve economic efficiency of regulations governing government sectors so as to reduce hidden costs, as well as avoiding efficiency loss. Moreover, strengthening ideological and moral education and supervision of regulatory authorities to prevent the occurrence of "regulatory capture" phenomenon. Finally, promoting the construction of external governance environment, reducing unnecessary government interventions in the economy, increasing the level of financial development as well as the level of the rule of law, and, allowing external governance environment to fully play the positive role towards business decision making.

Although a number of scholars have carried out empirical researches on how external governance environment impacts corporate over-investment using a single factor, but many are in-short of indepth analysis on how the entire external governance environment affect over-investment, and the literatures rarely take into account industry regulations which play a key role. Based on the law and finance theory, and the regulatory capture theory, we conduct a detailed analysis on how governance environment, industry regulation and over-investment relate to each other, and provide a novel perspective in understanding over-investment behavior in Chinese listed companies during China's economic transition period. But, the article still has a few shortcomings as are listed below; First of all, this paper defines the scope of regulated industries based on the principles in the strategic adjustment of state-owned economy: with the continuous development of economic transition and the state of economic reforms in related areas, and with the constant change in the scope of industrial regulations, thus, how substantiated is the established conclusion is highly uncertain, therefore we will be conducting a follow-up study. Second, factors affecting investment behavior are complicated, but we only considered the impact of external governance environment and industry regulations while ignoring the effect of nature of property rights, manager's reputation, just to mention a few, thus, we will be conducting an in-depth follow-up study. And, finally, as companies' investment activities vary widely, a simple model cannot fully interpret the economic significance of the investment activities. In the future, we will put more efforts into the research on the measurement of the level of corporate investment and efficiency. 


\section{Acknowledgement}

This work was financially supported by the National Natural Science Foundation of China (71172136).

\section{References}

Averch, H., \& Johnson, L. L. (1962). Behavior of the firm under regulatory constraint. The American Economic Review, 1052-1069.

Ahmed, A. S., \& Duellman, S. (2011). Evidence on the role of accounting conservatism in monitoring managers’ investment decisions. Accounting \& Finance, 51(3), 609-633.

Ang, J. S., Cole, R. A., \& Lin, J. W. (2000). Agency costs and ownership structure. The Journal of Finance, 55(1), 81-106.

Bai, C. E., Lu, J., \& Tao, Z. (2006). The multitask theory of state enterprise reform: empirical evidence from China. The American Economic Review, 353-357.

Bergman, N. K., \& Nicolaievsky, D. (2007). Investor protection and the Coasian view. Journal of Financial Economics, 84(3), 738-771.

Biddle, G. C., Hilary, G., \& Verdi, R. S. (2009). How does financial reporting quality relate to investment efficiency?. Journal of Accounting and Economics, 48(2), 112-131.

Black, B. (2001). The corporate governance behavior and market value of Russian firms. Emerging Markets Review, 2(2), 89-108.

Cambini, C., \& Rondi, L. (2010). Incentive regulation and investment: evidence from European energy utilities. Journal of Regulatory Economics,38(1), 1-26.

Chaney, P. K., Faccio, M., \& Parsley, D. (2011). The quality of accounting information in politically connected firms. Journal of Accounting and Economics, 51(1), 58-76.

D’Mello, R., \& Miranda, M. (2010). Long-term debt and overinvestment agency problem. Journal of Banking \& Finance, 34(2), 324-335.

Djankov, S., McLiesh, C., \& Shleifer, A. (2007). Private credit in 129 countries. Journal of financial Economics, 84(2), 299-329.

Fan, G., Wang, X., \& Zhu, H. (2010). NERI Index of Marketization of China's Provinces 2009 Report. Beijing: Economic Science Press.

Fang, J. (2006). Evolvement of marketization and improvement of capital allocation efficiency. Economic Research Journal, 5, 005.

Fazzari, S., Hubbard, R. G., \& Petersen, B. C. (1988). Financing constraints and corporate investment, 141-206.

García-Herrero, A., Gavila, S., \& Santabárbara, D. (2006). China's banking reform: an assessment of its evolution and possible impact. CESifo Economic Studies, 52(2), 304-363.

Jensen, M. C. (1986). Agency costs of free cash flow, corporate finance, and takeovers. The American economic review, 323-329.

La Porta, R., Lopez-de-Silanes, F., Shleifer, A., \& Vishny, R. (1999). The quality of government. Journal of Law, Economics, and organization, 15(1), 222-279.

La Porta, R., Lopez-de-Silanes, F., Shleifer, A., \& Vishny, R. W. (1998). Law and finance. Journal of Political Economy, 1113-1155.

Lang, M., Smith Raedy, J., \& Wilson, W. (2006). Earnings management and cross listing: Are reconciled earnings comparable to US earnings?. Journal of Accounting and Economics, 42(1), 255-283.

Levine, R., \& Zervos, S. (1998). Stock markets, banks, and economic growth. American Economic Review, 537-558.

North, D. C. (1990). Institutions, institutional change and economic performance. Cambridge university press.

Pagano, M., \& Volpin, P. F. (2005). The political economy of corporate governance. American Economic Review, 1005-1030. 
Perotti, E. C., \& von Thadden, E. L. (2006). The political economy of corporate control and labor rents. Journal of Political Economy, 114(1), 145-175.

Porta, R. L., Lopez-de-Silane, F., \& Zamarripa, G. (2003). Related lending. Quarterly Journal of Economics, 118(1):231-268.

Richardson, S. (2006). Over-investment of free cash flow. Review of Accounting Studies, 11(2-3), 159-189.

Roques, F. A., \& Savva, N. (2009). Investment under uncertainty with price ceilings in oligopolies. Journal of Economic Dynamics and Control, 33(2), 507-524.

Shleifer, A., \& Vishny, R. W. (1994). Politicians and firms. The Quarterly Journal of Economics, 995-1025.

Shleifer, A., \& Vishny, R. W. (2002). The grabbing hand: Government pathologies and their cures. Harvard University Press.

Simon, J., John, M., \& Christopher, W. (2002). Property Rights and Finance. American Economic Review, 92(5), 1335-1356.

Singh, M., \& Davidson III, W. N. (2003). Agency costs, ownership structure and corporate governance mechanisms. Journal of Banking \& Finance, 27(5), 793-816.

Takayama, A. (1969). Behavior of the firm under regulatory constraint. The American Economic Review, 255-260.

Vogt, S. C. (1994). The cash flow/investment relationship: evidence from US manufacturing firms. Financial management, 3-20.

Williamson, O. E. (2000). The new institutional economics: taking stock, looking ahead. Journal of Economic Literature, 595-613.

Xia, L., \& Fang, Y. (2005). Government Control, Institutional Environment and Firm Value: Evidence from the Chinese Securities Market. Economic Research Journal, 5, 40-51.

Yang, H., Hu, Y. (2007). Institution environment and over-investment of free cash flow. Management World, 9, 99-116. 